\title{
Infections and antibiotic therapy in patients after spine surgery in a 5-year follow-up study
}

\section{Type}

Research paper

\section{Keywords}

antibiotic therapy, spine surgery, surgical site infection

\begin{abstract}
Introduction

Infections after spinal surgery are sporadic and depend on the patient's condition and the type and extent of surgery. The incidence of surgical site infections in European centers ranges from $0 \%$ to $18 \%$. The aim of the study was to determine the frequency of infections in patients after spinal surgery.
\end{abstract}

Material and methods

The analysis covered 6067 patients who underwent spinal surgery in the Department of Neuroorthopedics between 2015-2019, taking into account the number of microbiological tests and the number of detected infections, the number of surgical procedures and the rate of SSI infections, the number of readmissions and reoperations, and the use of antibiotics. The analysis was based on retrospective data of patients hospitalized in the analyzed period.

\section{Results}

The number of operated patients remained at a similar level in the analyzed annual periods, from 1136 to 1269 patients, while the infection rate of the operated site ranged from $0,33 \%$ to $1,04 \%$, and the percentage of infections was between $0,58 \%$ and $3,29 \%$. In turn, the analysis of reoperations performed due to infection of the operated site in 2018 and 2019 was $0,56 \%$ and $0,07 \%$, respectively, which places the center in the leading position in the European ranking. During the analyzed five years, the use of antibiotics was reduced by $2 / 3$.

\section{Conclusions}

The analysis of infections in patients after spinal surgery over a 5-year period showed that the SSI rate did not exceed $1,04 \%$, which is comparable with data from recognized European centers. Infections caused by alarm pathogens have been detected occasionally. 


\section{SUMMARY}

Infections and antibiotic therapy in patients after spine surgery in a 5-year follow-up study Infections after spinal surgery are sporadic and depend on the patient's condition and the type and extent of surgery. The incidence of surgical site infections in European centers ranges from $0 \%$ to $18 \%$.

The aim of the study was to determine the frequency of infections in patients after spinal surgery, taking into account the profile of antibiotics used over 5 years.

Material and methods. The analysis covered 6067 patients who underwent spinal surgery in the Department of Neuroorthopedics between 2015-2019, taking into account the number of microbiological tests and the number of detected infections, the number of surgical procedures and the rate of SSI infections, the number of readmissions and reoperations, and the use of antibiotics. The analysis was based on retrospective data of patients hospitalized in the analyzed period.

Results. The number of operated patients remained at a similar level in the analyzed annual periods, from 1136 to 1269 patients, while the infection rate of the operated site ranged from $0,33 \%$ to $1,04 \%$, and the percentage of infections was between 0,58\% and 3,29\%. In turn, the analysis of reoperations performed due to infection of the operated site in 2018 and 2019 was $0,56 \%$ and $0,07 \%$, respectively, which places the center in the leading position in the European ranking. The analysis of antibiotics used in this group of patients shows that bactericidal antibiotics were mainly administered from $69,9 \%$ to $88,2 \%$, with a downward trend. During the analyzed five years, the use of antibiotics was reduced by $2 / 3$.

Conclusions. The analysis of infections in patients after spinal surgery over a 5-year period showed that the SSI rate did not exceed 1,04\%, which is comparable with data from recognized European centers. Infections caused by alarm pathogens have been detected occasionally. The use of antibiotics with bactericidal activity was undertaken in the majority of patients. The differences in the number and percentage of the analyzed parameters of infection in the operated patients were related to the general condition of the patients.

Key words: spine surgery, surgical site infection, antibiotic therapy

\section{STRESZCZENIE}

\section{Zakażenia i antybiotykoterapia u chorych po leczeniu operacyjnym kregostupa w 5-cio} letniej obserwacji

Zakażeniami po leczeniu operacyjnym kręgostupa zdarzaja się sporadycznie i pozostaja $w$ zależności od stanu chorego oraz typu i rozległości operacji. Częstość występowania zakażeń miejsca operowanego(ZMO) w ośrodkach europejskich waha się od $0 \%$ do $18 \%$. Celem pracy byto określenie czesstości występowania zakażeń u chorych po leczeniu operacyjnym kregostupa z uwzględnieniem profilu stosowanych antybiotyków w czasie 5 lat. Material $\boldsymbol{i}$ metody. Analiza objęto 6067 chorych operowanych w Oddziale Neuroortopedii w latach 2015-2019 uwzględniajac: liczbę wykonanych badań mikrobiologicznych i liczbe wykrytych zakażeń, liczbę zabiegów operacyjnych $i$ wskaźnik $Z M O$, liczbę readmisji i reoperacji oraz stosowania antybiotyków. Podstawa przeprowadzonej analizy byty dane retrospektywne chorych hospitalizowanych $w$ analizowanym okresie.

Wyniki. Liczba operowanych pozostawała $w$ analizowanych okresach rocznych na zbliżonym poziomie od 1136 do 1269 chorych, natomiast wskaźnik ZMO wynosit od 0,33\% do 1,04\%, a odsetek wszystkich zakażeń osiagat wartość od 0,58\% do 3,29\%. Z kolei przeprowadzona analiza wykonanych reoperacji z powodu zakażenia miejsca operowanego w roku 2018 i 2019 
wynosiła odpowiednio 0,56\% i 0,07\%, co plasuje ośrodek na czołowym miejscu $w$ rankingu europejskim. Analiza stosowanych antybiotyków w tej grupie chorych wskazuje, że głównie podawane byty antybiotyki bakteriobójcze $69,9 \%$ do $88,2 \%$, z tendencja zmniejszająca. W ciagu analizowanych pięciu lat zmniejszono zużycie antybiotyków prawie o 2/3.

Wnioski. Przeprowadzona analiza zakażeń $w$ ciagu 5-ciu lat u chorych po leczeniu operacyjnym kręgostupa wskazuje, że odsetek ZMO nie przekraczat 1,04\%, co jest porównywalne $z$ danymi $z$ uznanych ośrodków europejskich. Sporadycznie wykrywano zakażenia wywołane przez patogeny alarmowe. Stosowanie antybiotyków o działaniu bakteriobójczym podejmowano u większości leczonych. Stwierdzone różnice w liczbie i odsetku analizowanych parametrów zakażenia u operowanych były zwiazane ze stanem ogólnym chorych.

Słowa kluczowe: operacja kręgostupa, zakażenie miejsca operowanego,antybiotykoterapia

The number of patients with incidence of infection after surgical treatment of the spine is small, due to the implemented and widely respected rules of sanitary and epidemic procedures. Depending on the type of surgery, its extent, and the patient's general condition, the incidence of surgical site infection (SSI) after spine surgery ranges from $0 \%$ to $18,0 \%[1,2,3]$. The lowest percentage of SSI $(0,6-3,0 \%)$ is found after the simple lumbar decompression compared to the instrumental connection (6-18\%) [4].

Factors modified by SSI are those that can be eliminated or therapeutically corrected, including: prolonged hospitalizations, excessive intravenous antibiotics and reoperations to clean the wound [4], but also the adverse effects of glucocorticoids, nicotinism, alcohol abuse, obesity, and malnutrition comorbidities [5,6]. The non-modifiable factors of SSI are: advanced age of the patient, weakened immune response, diabetes, spinal cord injury, scoliosis and the need to undergo urgent surgical treatment (spinal injury), especially with blood transfusion $[6,8]$.

The aim of the study was to analyze the incidence of infection after surgical treatment of the spine and implemented antibiotic therapy. Over the last few years the infection rate and amount of used antibiotics has decreased. The authors wanted to emphasize the importance of appropriate procedures usage, implementation of unified and clear recommendations for all doctors working in our hospital.

The study assesses the incidence of infections in surgically treated patients over a 5year period, taking into account the profile of the used antibiotics. 


\section{MATERIAL AND METHODS}

The retrospective analysis of data stored in the hospital information system CGM

Clininet involved 6067 patients who underwent surgery in the Department of

Neuroorthopedics between 2015-2019, taking into account:

- the number of microbiological tests performed and the number of infections

detected,

- number of surgeries and SSI infection rate,

- number of readmissions and re-operations,

- use of antibiotics.

SSI in a healed surgical wound was diagnosed on the basis of clinical symptoms, laboratory tests and imaging diagnostics. Patients have reported pain in the operated area that was increasing over time, but also low-grade fever, sweating, general weakness, and loss of appetite. Laboratory tests of peripheral blood showed an increase in the parameters of inflammation (ESR and CRP). All patients underwent magnetic resonance imaging (MRI) or computed tomography (CT), which allowed for visualization of the extent of the infection and possible abscesses.

In order to determine the pathogen causing the infection, blood was collected for the culture of aerobic and anaerobic bacteria and fungi in patients with a healed surgical wound. Urine was collected in parallel for culture.

Antibiotic therapy was administered in accordance with the rational antibiotic policy program that has been in force at the center since 2015, in accordance with the obtained blood culture result, and in the case of a negative result, in accordance with the urine culture result.

If the urine culture was also sterile, then antibiotic therapy was administered empirically for infection with methicillin-susceptible Staphylococcus aureus and for those operated without implants, a beta-lactam antibiotic (cloxacillin $4 \times 2 \mathrm{~g} \mathrm{IV}$ ) was prescribed. In the case of SSI, the patients with implants were additionally treated with ansamycin derivatives (rifampicin 1 x 600 mg po.). After 2-4 weeks, the treatment was followed with oral antibiotics from the cephalosporin group (cephalexin 4 x $1 \mathrm{~g}$ ) and rifampicin $600 \mathrm{mg}$ once daily. Inflammation indices (ESR and CRP) were monitored during the treatment. In patients with a cutaneous fistula, swabs were always taken for culture and, according to the antibiotic, intravenous antibiotics were used to start with, and after about 10-14 days they were changed to oral preparations.

For the purposes of granting hospital accreditation by the Ministry of Health in 2018, 
the concept of readmission and reoperation for the Mazovian Rehabilitation Center was analyzed and defined:

- Readmission means re-admission to the ward of a patient treated surgically, regardless of indications for hospitalization, for up to a year, excluding scheduled admissions.

- Reoperation has been defined as a re-operation at the level or on the previously operated site, regardless of when it was initially performed.

In the case of SSI, patients with abscesses that penetrated the spinal canal and patients who did not respond to conservative treatment were qualified for reoperation. After cleansing the wound of pus, surgical sutures were placed on the fascia quite loosely and the drain was led out at the cutaneous incision site and kept for several days. The stand after its removal was kept open by unblocking it with a sterile probe. When the leakage from the wound had subsided, a swab was taken for culture. After obtaining a sterile result, wound drainage was stopped.

In patients with cutaneous fistula, vacuum treatment was helpful in healing the wound. Surgical closure of the fistula was performed in some patients with aseptic cultures.

\section{RESULTS}

The analysis of 6067 patients operated upon in the period 2015-2019 in the Department of Neuroorthopedics shows a slight variation in the number of patients treated in particular years (tab. 1). The number of microbiological tests performed during this period was variable and depended on the profile of the treated patients, including those admitted on an emergency basis. The percentage of infections found in the operated patients ranged from $0,58 \%$ to $3,29 \%$.

It should be emphasized that the application of strict criteria for infectious agents (Harris questionnaire) and internal medicine examinations performed in patients admitted to elective surgeries made it possible to preemptively eliminate potential complications in the perioperative period. This type of procedure was not possible in patients admitted urgently after accidents, injuries, etc.

Table 1. The number of operations, surgical site infections, microbiological tests performed and confirmed infections in 2015-2019 in relation to the number of patients.

\begin{tabular}{|l|c|c|c|c|c|}
\hline Parameters & $\mathbf{2 0 1 5}$ & $\mathbf{2 0 1 6}$ & $\mathbf{2 0 1 7}$ & $\mathbf{2 0 1 8}$ & $\mathbf{2 0 1 9}$ \\
\hline $\begin{array}{l}\text { Number of } \\
\text { operated }\end{array}$ & 1136 & 1192 & 1225 & 1245 & 1269 \\
\hline
\end{tabular}




\begin{tabular}{|c|c|c|c|c|c|}
\hline $\begin{array}{l}\text { Number and rate } \\
(\%) \text { of surgical } \\
\text { site infections }\end{array}$ & $\begin{array}{c}4 \\
(0,35 \%)\end{array}$ & $\begin{array}{c}4 \\
(0,33 \%)\end{array}$ & $\begin{array}{c}11 \\
(0,89 \%)\end{array}$ & $\begin{array}{c}13 \\
(1,04 \%)\end{array}$ & $\begin{array}{c}7 \\
(0,55 \%)\end{array}$ \\
\hline $\begin{array}{l}\text { Number and } \\
\text { percentage }(\%) \\
\text { of } \\
\text { microbiological } \\
\text { tests performed }\end{array}$ & $\begin{array}{c}130 \\
(11,40 \%)\end{array}$ & $\begin{array}{c}183 \\
(15,35 \%)\end{array}$ & $\begin{array}{c}173 \\
(14,12 \%)\end{array}$ & $\begin{array}{c}381 \\
(30,60 \%)\end{array}$ & $\begin{array}{c}263 \\
(18,59 \%)\end{array}$ \\
\hline $\begin{array}{l}\text { Number and } \\
\text { percentage }(\%) \\
\text { of confirmed } \\
\text { infections }\end{array}$ & $\begin{array}{c}7 \\
(5,38 \%)\end{array}$ & $\begin{array}{c}7 \\
(3,82 \%)\end{array}$ & $\begin{array}{c}12 \\
(6,94 \%)\end{array}$ & $\begin{array}{c}41 \\
(10,76 \%)\end{array}$ & $\begin{array}{c}20 \\
(7,60 \%)\end{array}$ \\
\hline $\begin{array}{l}\text { Percentage of } \\
\text { infections }\end{array}$ & $0,61 \%$ & $0,58 \%$ & $0,97 \%$ & $3,29 \%$ & $1,57 \%$ \\
\hline
\end{tabular}

The analysis of the number of performed surgeries and confirmed SSI indicates their relative increase in 2018 above 1\% (tab. 2). Regardless of the differences in years, such a low infection rate does not allow to accurately define the group of patients at increased risk in the analyzed material.

The pathogens identified in the cultures of material obtained from the operated sites and from postoperative wounds were diverse (tab. 2). The table does not include pathogens responsible for urinary tract infection. However, it is noteworthy that infections caused by alarm bacteria, including methicillin-resistant Staphylococcus aureus, were found sporadically in patients after spinal surgery.

Table 2. Number of bacterial pathogens irrefutably detected in the material from the surgical site and from postoperative wounds.

\begin{tabular}{|c|c|c|c|c|c|}
\hline Pathogen & 2015 & 2016 & 2017 & 2018 & 2019 \\
\hline $\begin{array}{l}\text { methicillin-resistant } \\
\text { Staphylococcus aureus }\end{array}$ & & 3 & 3 & 3 & 2 \\
\hline Staphylococcus epidermidis & 1 & 4 & 1 & 3 & \\
\hline $\begin{array}{l}\text { ESBL-positive Klebsiella } \\
\text { pneumoniae }\end{array}$ & 1 & & 1 & & \\
\hline
\end{tabular}




\begin{tabular}{|c|c|c|c|c|c|}
\hline Acinetobacter baumannii & 1 & 1 & & 1 & 2 \\
\hline Clostridium difficile & 1 & & & & \\
\hline Enterococcus faecium & 1 & 2 & 2 & 2 & 3 \\
\hline Escherichia coli & & 2 & & & \\
\hline $\begin{array}{l}\text { Streptococcus para } \\
\text { sanguinis/mitis }\end{array}$ & & 2 & & 1 & \\
\hline Pseudomonas aeruginosa & & 1 & & & 1 \\
\hline Proteus mirabilis & & & 1 & & \\
\hline Serratia marcescens & & & 1 & & 2 \\
\hline Citrobacter freundii & & & 1 & & \\
\hline Morganella morgani & & & 1 & & \\
\hline Candida albicans & & 1 & & & 1 \\
\hline
\end{tabular}

In 2018, 7 patients required reoperation and 6 patients required readmission due to SSI, and in 2019 only one patient. The analysis shows that the reoperation rates due to SSI in 2018 and 2019 were $0,56 \%$ and $0,07 \%$, respectively. SSI accounted for $4,5 \%$ and $0,6 \%$ causes of all reoperations, and 31,6\% and 11\% causes of all readmissions in 2018 and 2019, respectively (tab. 3).

Table 3. Number and percentage of reoperations and readmissions due to SSI in 20182019.

\begin{tabular}{|c|c|c|c|c|c|c|c|}
\hline Year & $\begin{array}{c}\text { Number of } \\
\text { operations }\end{array}$ & $\begin{array}{c}\text { Number of } \\
\text { reoperations } \\
\mathbf{n}(\%)\end{array}$ & $\begin{array}{c}\text { Reoperations } \\
\text { due to SSI } \\
\mathbf{n}(\%)\end{array}$ & $\begin{array}{c}\text { SSI in } \\
\text { reoperated } \\
\text { group } \\
(\%)\end{array}$ & $\begin{array}{c}\text { Number of } \\
\text { readmissio } \\
\mathbf{n} \\
\mathbf{n}(\%)\end{array}$ & $\begin{array}{c}\text { Readmissions } \\
\text { due to SSI } \\
\mathbf{n}(\%)\end{array}$ & $\begin{array}{c}\text { SSI in } \\
\text { readmission } \\
\text { group } \\
(\%)\end{array}$ \\
\hline 2018 & 1245 & $\begin{array}{c}156 \\
(12,53 \%)\end{array}$ & $7(0,56 \%)$ & $4,5 \%$ & $\begin{array}{c}19 \\
(1,53 \%)\end{array}$ & $\begin{array}{c}6 \\
(0,48 \%)\end{array}$ & $36,6 \%$ \\
\hline 2019 & 1269 & $\begin{array}{c}157 \\
(12,37 \%)\end{array}$ & $\begin{array}{c}1 \\
(0,07 \%)\end{array}$ & $0,6 \%$ & $\begin{array}{c}9 \\
(0,71 \%)\end{array}$ & $\begin{array}{c}1 \\
(0,07 \%)\end{array}$ & $11 \%$ \\
\hline
\end{tabular}


The analysis of antibiotics used in patients hospitalized in the ward was performed, taking into account the groups of drugs and the number of doses administered (tablets and injections) (tab. 4). It was shown that the profile of the preparations used was changing and depended on the current recommendations and the epidemic situation in individual years.

Table 4. List of antibiotics administered to patients hospitalized in the ward in the analyzed periods.

\begin{tabular}{|c|c|c|c|c|c|c|}
\hline \multicolumn{2}{|c|}{ Antibiotic group } & 2015 & 2016 & 2017 & 2018 & 2019 \\
\hline \multicolumn{2}{|c|}{ Bactericidal } & \multicolumn{5}{|c|}{ Number of doses $(\%)$} \\
\hline \multicolumn{2}{|c|}{ Aminoglycosides } & 60 & 60 & 10 & 50 & 20 \\
\hline \multirow{3}{*}{$\begin{array}{c}\beta \\
- \\
1 \mathrm{a} \\
\mathrm{ct} \\
\mathrm{a} \\
\mathrm{m} \\
\mathrm{s}\end{array}$} & Penicillins & $\begin{array}{c}10300 \\
(82,92 \%)\end{array}$ & $\begin{array}{c}6803 \\
(69,67 \%)\end{array}$ & $\begin{array}{c}1455 \\
(31,20 \%)\end{array}$ & $\begin{array}{c}1402 \\
(29,24 \%)\end{array}$ & $\begin{array}{c}654 \\
(18,31 \%)\end{array}$ \\
\hline & Cephalosporins & $\begin{array}{c}1080 \\
(8,68 \%)\end{array}$ & $\begin{array}{c}1650 \\
(16,89 \%)\end{array}$ & $\begin{array}{c}2729 \\
(58,51 \%)\end{array}$ & $\begin{array}{c}2540 \\
(52,98 \%)\end{array}$ & $\begin{array}{c}2251 \\
(63,04 \%)\end{array}$ \\
\hline & Carbapenems & $\begin{array}{c}330 \\
(2,66 \%)\end{array}$ & $\begin{array}{c}80 \\
(0,82 \%)\end{array}$ & $\begin{array}{c}90 \\
(1,93 \%)\end{array}$ & $\begin{array}{c}30 \\
(0,62 \%)\end{array}$ & $\begin{array}{c}20 \\
(0,56 \%)\end{array}$ \\
\hline \multicolumn{2}{|c|}{ Fluoroquinolones } & $\begin{array}{c}200 \\
(1,62 \%)\end{array}$ & $\begin{array}{c}840 \\
(8,61 \%)\end{array}$ & $\begin{array}{c}195 \\
(4,18 \%)\end{array}$ & $\begin{array}{c}600 \\
(12,53 \%)\end{array}$ & $\begin{array}{c}318 \\
(8,90 \%)\end{array}$ \\
\hline \multicolumn{2}{|c|}{ Glycopeptides } & $\begin{array}{c}120 \\
(0,96 \%)\end{array}$ & $\begin{array}{c}75 \\
(0,76 \%)\end{array}$ & $\begin{array}{c}5 \\
(0,11 \%)\end{array}$ & $\begin{array}{c}20 \\
(0,42 \%)\end{array}$ & $\begin{array}{c}25 \\
(0,71 \%)\end{array}$ \\
\hline \multicolumn{2}{|c|}{ Ansamycines } & $\begin{array}{c}121 \\
(0,97 \%)\end{array}$ & $\begin{array}{c}66 \\
(0,67 \%)\end{array}$ & $\begin{array}{c}12 \\
(0,26 \%)\end{array}$ & $\begin{array}{c}12 \\
(0,25 \%)\end{array}$ & $\begin{array}{c}123 \\
(3,44 \%)\end{array}$ \\
\hline \multicolumn{2}{|c|}{ Polymyxini } & $\begin{array}{c}60 \\
(0,49 \%)\end{array}$ & $\begin{array}{c}32 \\
(0,33 \%)\end{array}$ & $\begin{array}{c}48 \\
(1,03 \%)\end{array}$ & - & $\begin{array}{c}120 \\
(3,36 \%)\end{array}$ \\
\hline \multicolumn{2}{|c|}{ Nitroimidazoles } & $\begin{array}{c}150 \\
(1,21 \%)\end{array}$ & $\begin{array}{c}160 \\
(1,64 \%)\end{array}$ & $\begin{array}{c}120 \\
(2,57 \%)\end{array}$ & $\begin{array}{c}140 \\
(2,92 \%)\end{array}$ & $\begin{array}{c}40 \\
(1,12 \%)\end{array}$ \\
\hline \multicolumn{2}{|c|}{ Total } & $\begin{array}{c}12421 \\
(88,2 \%)\end{array}$ & $\begin{array}{c}9766 \\
(83,1 \%)\end{array}$ & $\begin{array}{c}4664 \\
(69,9 \%)\end{array}$ & $\begin{array}{c}4794 \\
(76,2 \%)\end{array}$ & $\begin{array}{c}3571 \\
(\mathbf{7 3 , 8 \%})\end{array}$ \\
\hline
\end{tabular}




\begin{tabular}{|c|c|c|c|c|c|}
\hline Antibiotic group & 2015 & 2016 & 2017 & 2018 & 2019 \\
\hline Bacteriostatic & \multicolumn{5}{|c|}{ Number of doses (\%) } \\
\hline Tetracyclines & $\begin{array}{c}70 \\
(4,20 \%)\end{array}$ & $\begin{array}{c}210 \\
(10,57 \%)\end{array}$ & & $50(333 \%)$ & - \\
\hline Lincosamines & $\begin{array}{c}35 \\
(2,10 \%)\end{array}$ & - & $\begin{array}{c}225 \\
(11,19 \%)\end{array}$ & $\begin{array}{c}129 \\
(8,59 \%)\end{array}$ & $\begin{array}{c}111 \\
(8,76 \%)\end{array}$ \\
\hline Macrolides & $\begin{array}{c}84 \\
(5,03 \%)\end{array}$ & $\begin{array}{c}200 \\
(10,07 \%)\end{array}$ & $\begin{array}{c}120 \\
(5,97 \%)\end{array}$ & $\begin{array}{c}312 \\
(20,79 \%)\end{array}$ & $\begin{array}{c}224 \\
(17,68 \%)\end{array}$ \\
\hline Oxazolidinones & - & - & - & $\begin{array}{c}50 \\
(3,33 \%)\end{array}$ & - \\
\hline Poliens & - & $\begin{array}{c}16 \\
(0,81 \%)\end{array}$ & $\begin{array}{c}16 \\
(0,79 \%)\end{array}$ & - & $\begin{array}{c}72 \\
(5,68 \%)\end{array}$ \\
\hline Sulfonamides & $\begin{array}{c}100 \\
(5,99 \%)\end{array}$ & - & $\begin{array}{c}180 \\
(8,96 \%)\end{array}$ & - & $\begin{array}{c}20 \\
(1,58 \%)\end{array}$ \\
\hline Furazidin & $\begin{array}{c}1380 \\
(82,68 \%)\end{array}$ & $\begin{array}{c}1560 \\
(78,55 \%)\end{array}$ & $\begin{array}{c}1410 \\
(70,11 \%)\end{array}$ & $\begin{array}{c}960 \\
(63,96 \%)\end{array}$ & $\begin{array}{c}840 \\
(66,30 \%)\end{array}$ \\
\hline Total & $\begin{array}{c}1669 \\
(11,8 \%)\end{array}$ & $\begin{array}{c}1986 \\
(16,9 \%)\end{array}$ & $\begin{array}{c}2011 \\
(30,1 \%)\end{array}$ & $\begin{array}{c}1501 \\
(23,8 \%)\end{array}$ & $\begin{array}{c}1267 \\
(26,2 \%)\end{array}$ \\
\hline $\begin{array}{l}\text { Bactericidal } \\
\text { and } \\
\text { bacteriostatic }\end{array}$ & 14090 & 11752 & 6675 & 6295 & 4838 \\
\hline
\end{tabular}

The main group of antibiotics used were bactericidal preparations (from 69,9\% to $88,2 \%$ ), including cephalosporins and synthetic penicillins. On the other hand, in the group of bacteriostatic antibiotics after furazidin, macrolides dominated, which, according to the implemented recommendations, controlled infections caused by intracellular pathogens. This direction of treatment turned out to be effective as there were no recurrences of infections and no need for reoperation.

Particularly noteworthy is the significant - over 3 times - reduction in the use of antibiotics from over 14000 doses in 2015 to almost 5000 in 2019, with a comparable number 
of surgeries performed each year.

\section{DISCUSSION}

A surgical site infection (SSI) is defined as an infection found up to 30 or 90 days following surgery, depending on the operating procedure [9]. Despite the implemented prophylaxis and microbiological supervision, SSI remains a significant clinical problem that extends hospitalization time and increases mortality. Epidemic studies have shown that SSI is found in about $3 \%$ of all operated patients, and $20 \%$ of those operated upon in emergency cases $[10]$.

The analysis of patients operated on in the Department of Neuroorthopedics showed that the percentage of all microbiological examinations ranged from $11,4 \%$ to $30,6 \%$, and the number of confirmed infections varied and ranged from $3,82 \%$ up to $10,76 \%$. The overall assessment showed that the percentage of all infections in hospitalized patients ranged from $0,61 \%$ in 2016 to $3,29 \%$ in 2018 (tab. 1). The revealed differences were caused by the profile of patients, including those admitted urgently. Regardless, the incidence of postoperative complications in analyzed groups was low in comparison to other centers where $8 \%$ of pneumonia were diagnosed [11].

In turn, in the analyzed period, the SSI percentage did not exceed 1,04\% (tab. 1), which places the center among the leaders in the European ranking [1,2,3]. However, it is disturbing that alarm pathogens were also sporadic among the detected pathogens (tab. 2), which required special supervision and long-term antibiotic therapy.

This type of assessment should take into account the nature of the operations performed, including their extent, duration and coexistence of other diseases [6,7]. It is known that the number of perioperative factors takes into account both the degree of invasiveness of the operation, its site, and the use of implants, which affects the risk of SSI (tab. 5) [7].

Table 5. Perioperative factors increasing the risk of SSI [7]

Surgical invasiveness index

Type of fusion

Implants use

Revision intervention 
Traditional open approach - compared to minimally invasive approach

Site of surgery - dorsal surgeries with highest infective risk compared to cervical and lumbar locations

Omission of drain usage post spine surgery

Exhaled oxygen below 50\%

Duration of surgery more than 3 hours

Stainless steel versus titanium tools

Perioperative management is also important. The use of antibiotics according to standard recommendations gives measurable effects in the form of reducing the number of infectious complications [12]. This is confirmed by the presented analysis, which is based on the current classification of antibacterial drugs (tab. 6) [13]. It has been shown that the use of bactericidal antibiotics, including rifampicin and vancomycin, was undertaken for reoperations in cases of infections confirmed by antibiotics (tab. 3). Among bacteriostatic antibiotics, the second most frequently used, after furazidin, were macrolides, including azithromycin, which allowed patients to achieve full effectiveness of infection control.

Table 6. The classification of antibacterial drugs [13].

\begin{tabular}{|c|c|c|c|c|}
\hline \multicolumn{3}{|c|}{ Bactericidal antibiotics } & \multicolumn{2}{|c|}{ Bacteriostatic antibiotics } \\
\hline \multicolumn{2}{|c|}{ Group } & Preparates & Group & Preparates \\
\hline \multicolumn{2}{|c|}{ Aminoglycosides } & $\begin{array}{l}\text { Amikacin } \\
\text { Gentamycin } \\
\text { Streptomycin } \\
\text { Tobramycin }\end{array}$ & Tetracyclines & $\begin{array}{l}\text { Doxycycline } \\
\text { Minocycline }\end{array}$ \\
\hline \multirow{3}{*}{$\begin{array}{c}\text { Be } \\
\mathbf{t} \\
\mathbf{a}- \\
\text { lac } \\
\mathbf{t} \mathbf{a} \\
\mathrm{ms}\end{array}$} & Penicillins & $\begin{array}{l}\text { Amoxiclav } \\
\text { Amoxicillin } \\
\text { Syntarpen }\end{array}$ & Macrolides & $\begin{array}{l}\text { Azithromycin } \\
\text { Clarithromycin }\end{array}$ \\
\hline & \multirow[t]{2}{*}{ Cephalosporins } & \multirow{2}{*}{$\begin{array}{l}\text { Cefazolin } \\
\text { Cefuroxime } \\
\text { Biotrakson } \\
\text { Biotum }\end{array}$} & & \\
\hline & & & Lincosamides & Clindamycin \\
\hline
\end{tabular}




\begin{tabular}{|c|c|c|c|}
\hline & Cefuroxime & Oxazolidines & Linezolid \\
\hline Carbapenems & $\begin{array}{l}\text { Imipenem } \\
\text { Meropenem }\end{array}$ & & \\
\hline Fluoroquinolones & $\begin{array}{l}\text { Ciprofloxacin } \\
\text { Levofloxacin } \\
\text { Moxifloxacin }\end{array}$ & Sulfonamides & $\begin{array}{l}\text { Sulfamethoxazole } \\
\text { Trimethoprim }\end{array}$ \\
\hline Glycopeptides & Vancomycin & & \\
\hline Polimyxines & $\begin{array}{l}\text { Colistin } \\
\text { Dalacin }\end{array}$ & Poliens & Nystatin \\
\hline Ansamycines & Rifampicin & & \\
\hline Nitroimidazoles & Metronidazole & Furazidin & Furagin \\
\hline
\end{tabular}

Nosocomial infections are still a clinical problem, therefore the efforts are still being made to improve prophylaxis methods and effective antibacterial treatment [14]. The modern strategy of using antibiotics, which are administered as preventive measures, should take into account the end result, minimizing side effects and reducing the risk of drug resistance. According to the developed recommendations, treatment with antibiotics begins with empirical therapy, and after the microbiological test results are obtained, targeted therapy $[15,16]$.

The validity of the application of recommendations in the antibiotic treatment of infections in neuroorthopedics, with particular emphasis on SSI, was confirmed in the analysis, showing a significant reduction in their consumption in 2019 compared to the data from 2015. Granting hospital accreditation by the Quality Monitoring Centre (Ministry of Health unit) required implementation of rational antibiotic therapy protocols. The analysis of most frequent nosocomial pathogens, types of infections were made, also all available antibiotics were presented and compiled in a collection of recommendations for all doctors working in our hospital. Detailed analysis and implementation of adequate protocols on dealing with particular cases enabled to apply more precise treatment of postoperative infections, as evidenced by decrease of antibiotic usage from 2019. 


\section{CONCLUSIONS}

Based on the analysis of infections in the neuroorthopedics ward over the five-year period, it can be concluded that:

- the percentage of infections in patients operated on due to diseases of the spine ranged from $0,61 \%$ to $3,29 \%$,

- SSI percentage did not exceed $1,04 \%$, which places the center among the leaders in the European ranking,

- infections caused by alarm pathogens were detected sporadically,

- the use of antibiotics with a bactericidal effect was undertaken in the majority of patients, while in about $20 \%$ of patients bacteriostatic drugs were administered, obtaining full effectiveness of infection control,

- the differences in the number and percentage of the analyzed parameters of infection in hospitalized patients were related to the general condition of patients, - the applied sanitary and epidemic procedures, taking into account the rational antibiotic policy, contributed to keeping the infection rate at a low level,

- implementation of the policy of rational antibiotic therapy and obtaining accreditation contributed to a significant reduction in the use of antibiotics.

\section{REFERENCES}

1. Gerometta A, Rodriguez Olaverri JC, et al.: Infections in spinal instrumentation. Int Orthop. 2012; 36(2):457-64.

2. Sharif S, Gulzar F. Postoperative infections of the spine. World Spinal Column J. 2015;1:19-26.

3. Tomov M, Mitsunaga L, Durbin-Johnson B, et al.: Reducing surgical site infection in spinal surgery with betadine irrigation and intrawound vancomycin powder. Spine (Phila Pa 1976). 2015; 40(7): 491-499. doi:10.1097/BRS.0000000000000789.

4. Parchi PD, Evangelisti G, Andreani L, et al.: Postoperative spine infections. Orthop Rev (Pavia). 2015;7:5900.

5. Lazennec JY, Fourniols E, Lenoir T, et al. Infections in the operated spine: update on risk management and therapeutic strategies. Orthop Traumatol Surg Res. 2011; 97(6 Suppl):S107-16.

6. Anderson PA, Savage JW, Vaccaro AR, et al.: Prevention of surgical site infection in spine surgery. Neurosurgery. 2017;80(3S): S114-S123.

7. Chahoud J, Kanafani Z, Kanj SS.: Surgical site infections following spine surgery: 
eliminating the controversies in the diagnosis. Front Med, 2014; 1(7):1-10. 8. Dowdell J, Brochin R, Kim J, et al.: Postoperative spine infection: diagnosis and management.

Global Spine J. 2018; 8(4S): 37S-43S

9. Gospodarek E, Szopiński J, Mikucka A.: Zakażenie miejsca operowanego - postaci kliniczne, czynniki ryzyka, profilaktyka, etiologia, diagnostyka. Forum Zakażeń, 2013; 4: 275-282.

10. Saha AK, Chowdhury F, Jha AK, et al.: Mechanical bowel preparation versus no preparation before colorectal surgery: A randomized prospective trial in a tertiary care institute. J Nat Sci Biol Med, 2014; 5: 421-424.

11. Street JT, Lenehan BJ, DiPaola CP, et al.: Morbidity and mortality of major adult spinal surgery. A prospective cohort analysis of 942 consecutive patients. Spine J. 2012;12(1):22-34. doi: 10.1016/j.spinee.2011.12.003.

12. Konieczny R, Płusa T, Baranowska A, i wsp.: Zakażenie miejsca operowanego po operacjach kręgosłupa. Internat Rev Med Pract. 2019; 25(1):33-37.

13. Calhoun C, Hall GA.: Antibiotics. StatPearls Publishing LLC. 2018.

14. Baranowski P, Płusa T, Baranowska A.:The risk of perioperative infections after orthopedic surgery. Pol Med J, 2018; XLIV (260); 82-8.

15. Hryniewicz W, Małdyk P, Ozorowski T, i wsp.: Profilaktyka, diagnostyka i terapia zakażeń w ortopedii. Narodowy Program Ochrony Antybiotyków na lata 2011-2015. Warszawa, 2013.

16. Płusa T, Konieczny R, Baranowska A, i wsp.: Narastająca oporność szczepów bakteryjnych na działanie antybiotyków. Pol Merkur Lekarski, 2019; XLVII (279); 106110 
